\section{Bottle Gourd Genotypes Vary in Clomazone Tolerance}

\author{
Matthew A. Cutulle ${ }^{1}$ \\ Clemson University Coastal Research and Extension Center, Charleston, SC \\ 29414-5334
}

\section{Howard F. Harrison, Jr., Chandresakar S. Kousik, Phillip A. Wadl, and Amnon Levi \\ U.S. Department of Agriculture, Agriculture Research Service, U.S. Vegetable Laboratory, Charleston, SC 29414-5334}

Additional index words. herbicide tolerance, clomazone, 2-[(2-chlorophenyl)methyl]-4, 4-dimethyl-3-isoxazolidinone, Lagenaria siceraria (Mol.) Standl, cucurbit

\begin{abstract}
A greenhouse trial was used to evaluate 159 accessions of bottle gourd [Lagenaria siceraria (Mol.) Standl.] obtained from the U.S. National Plant Germplasm for tolerance to clomazone herbicide. Most accessions tested were moderately or severely injured by clomazone at $3.0 \mathrm{mg} \cdot \mathrm{kg}^{-1}$ incorporated into greenhouse potting medium; however, several exhibited lower injury. Seeds were produced from tolerant and susceptible plants for use in a greenhouse concentration-response experiment. About three to four times higher clomazone concentrations were required to cause moderate injury to tolerant bottle genotypes in comparison with susceptible genotypes. The differences in tolerance among genotypes were observed with injury ratings, chlorophyll measurements, and shoot weights. Clomazone may be used safely on tolerant bottle gourd genotypes, but the herbicide may not be safe for susceptible genotypes. Also, tolerant genotypes such as Grif 11942 may be desirable for use as rootstocks in grafted watermelon production.
\end{abstract}

Lagenaria siceraria (Mol.) Standl., a viny species of the Cucurbitaceae family, is thought to be among the first domesticated plant species (Cutler and Whitaker, 1967). Its dry, mature fruit is used by people throughout the world for making jars, utensils, tubes, and musical instruments, is used as a vegetable, and is commonly known as the bottle gourd (Decker-Walters et al., 2001, 2004; Erickson et al., 2005). It is also known as the whiteflowered gourd or calabash (Jeffrey, 1967). Bottle gourd is indigenous to Africa (Morimoto et al., 2006; Richardson, 1972); however, remains found in archeological digs point to the possibility that it reached temperate and tropical areas in Asia and the Americas over 10,000 years ago. The increased geographical distribution of the bottle gourd plant is likely due to human migration (Erickson et al., 2005), though dispersion of bottle gourd could have occurred through movement across oceans. Bottle gourd fruits are known to have the capacity to float on seas for many months without losing seed viability (Decker-Walters et al., 2004). The crop thrives in a wide range of soil types and is more tolerant of a high water table (Yetisir et al., 2006) and to salt than watermelon Citrullus lanatus (Thunb) Matsum and Nakai (Colla et al., 2005). In addition to the aforementioned

Received for publication 12 June 2017. Accepted for publication 6 Oct. 2017.

${ }^{1}$ Corresponding author. E-mail: mcutull@clemson. edu.

HortScience Vol. 52(12) December 2017 the U.S. National Plant Germplasm collection; however, other accessions of $C$. lanatus var. citroides were highly susceptible. About 5-fold higher clomazone concentrations were required to cause equivalent injury and growth reduction in the most tolerant genotypes when compared with susceptible genotypes in a greenhouse concentration-response experiment. Hines and Wilson (1992) also reported that watermelon cultivars varied in clomazone injury in a greenhouse experiment. Staub et al. (1991) screened the U.S. National Plant Germplasm collection of cucumber for clomazone tolerance in the field and identified tolerant and susceptible accessions based on injury ratings. In a greenhouse evaluation of selected accessions, the relative differences in tolerance of the accessions did not range as much as those observed in the field. Al-Khatib et al. (1995) reported differences in clomazone tolerance among five cucumber cultivars in greenhouse and field experiments. Following the observation of differences in clomazone injury in a field trial, Harrison and Keinath (2003) evaluated 67 pumpkin (Cucurbita maxima Pang) cultivars for tolerance in the greenhouse. Differences in tolerance were greatest between the species marketed as pumpkins; however, differences in tolerance were also observed among cultivars within species. Thus, there is a precedent of clomazone tolerance being variable among varieties of cucurbit species. Watermelon was the most sensitive to clomazone when compared with honeydew (Cucumis melo L. var. inodorus Naud), zucchini (Cucurbita pepo L.), winter squash (C. maxima Duch, Ex. Poiret), cucumber (Cucumis sativus L.), and muskmelon (Cucumis melo L. var. reticulatus Naud) (Figueroa and Kogan, 2005) based on early season injury ratings and growth measurements. However, clomazone at up to 0.9 $\mathrm{kg} \cdot \mathrm{ha}^{-1}$ did not affect watermelon crop yields. Boyhan et al. (1995) reported that watermelon yields were reduced by clomazone applied PRE at $1.1 \mathrm{~kg} \cdot \mathrm{ha}^{-1}$ to direct seeded watermelon. Grey et al. (2000) reported that clomazone applied preplant incorporated at 0.84 $\mathrm{kg} \cdot \mathrm{ha}^{-1}$, preplant to the soil surface, and posttransplant to the soil surface caused minor foliar bleaching (14\% injury or less), but did not reduce the yields of seeded or transplanted 'Royal Sweet' watermelon. Cohen et al. (2008) concluded from a greenhouse study that clomazone applied at 1.0 and $2.0 \mathrm{~kg} \cdot \mathrm{ha}^{-1}$ was too injurious to grafted and nongrafted watermelons. Variation among cultivars in clomazone tolerance has been reported in several non-cucurbit crops, including bean (Sikkema et al., 2006), cabbage (Hopen et al., 1992), corn (Keifer, 1989), rice (Mudge et al., 2005; Scherder et al., 2004; Zhang et al., 2004), and sweetpotato (Harrison and Jackson, 2011). The variable tolerance observed in other crops necessitates screening a large number of bottle gourd accessions for clomazone sensitivity to increase the probability of finding a line with high tolerance.

The objectives of these greenhouse experiments were to assess the variability of clomazone tolerance in an extensive bottle gourd germplasm collection and to identify lines with high levels of tolerance. The 
potential end application would be to select clomazone-tolerant bottle gourd lines that could be used as rootstock to graft to watermelon scions. In the past, bottle gourd rootstock had effectively improved salt tolerance to the watermelon scion (Colla et al., 2010). Certain bottle gourd lines are resistant to multiple viruses that would infect economically important watermelon lines (Ling et al., 2013). Crown rot (Phytophthora capsici Leonian) disease, root-knot nematodes, and whiteflies are reduced with certain bottle gourd varieties as well (Kousik et al., 2012; Levi et al., 2009). A dose-response experiment was conducted to quantify the difference in tolerance between the most and least tolerant accessions.

\section{Materials and Methods}

The greenhouse used in these experiments was located at the U. S. Vegetable Laboratory, Charleston, SC. Temperatures in the greenhouse ranged between 20 and $32{ }^{\circ} \mathrm{C}$, supplemental lighting was not provided, and humidity was increased from ambient to $80 \%$ by using an evaporative cooling system. The greenhouse potting medium was a $1 / 1(\mathrm{v} / \mathrm{v})$ blend of a commercial potting mixture (Metro-Mix 360; Sun Gro Horticulture Distribution Inc., Bellevue, WA) and washed river sand. Powdered limestone and controlled release fertilizer (Osmocote 15-9-12 plus; The Scotts Co. LLC, Marysville, OH) at $1.1 \mathrm{~g} \cdot \mathrm{L}^{-1}$ were added, and the mixture was blended in a portable cement mixer for $5 \mathrm{~min}$. Clomazone was incorporated into the potting medium by adding the commercial formulation (Command 3 ME; FMC Corp., Philadelphia, PA) to $500 \mathrm{~mL}$ of water, spraying the dilution directly onto the potting mixture in a concrete mixer using a handheld sprayer, followed by mixing for $10 \mathrm{~min}$. A clomazone concentration of $3.0 \mathrm{mg} \cdot \mathrm{kg}^{-1}$ dry potting mix was selected for germplasm evaluation based on the results of a preliminary experiment that indicated this concentration caused moderate injury to bottle gourd. The clomazone-treated potting mixture was used to fill $475-\mathrm{mL}$ polystyrene foam cups. Seeds were planted in cups containing clomazonetreated soil and placed in the greenhouse. The cups were watered as necessary to maintain moist the potting mixture. After 3 weeks, the plants were rated for clomazone injury on a 0 to 10 scale, where $0=$ no chlorosis, $3=\approx 30 \%$ of shoot tissue chlorotic, $7=\approx 70 \%$ of tissue chlorotic, and $10=$ plants completely chlorotic or dead.

A preliminary germplasm evaluation experiment included commercial rootstock cultivars and 159 germplasm accessions of bottle gourd obtained from the U.S. Plant Germplasm System. The planting dates for the first and second experimental runs were 28 May and 26 June 2008, respectively. This experiment was arranged in a randomized complete block design with three replications for the first experiment and four replications for the second experiment. Ratings for accessions with at least four plants were subjected to analysis of variance (ANOVA) and the $\mathrm{LSD}_{0.05}$ was determined. Data for all visual ratings were converted to percentages and then subjected to arcsine transformation before ANOVA using Proc Mix in SAS (SAS Institute Inc., Cary, NC). Interpretations were not different from nontransformed data and normality was acceptable based on the Shapiro-Wilk diagnostic test; thus, nontransformed means are presented for clarity.

Table 1. Injury ratings for 159 accessions from the U.S. Plant Introduction collection of bottle gourd genotypes in response to clomazone incorporated into the greenhouse potting medium at $3 \mathrm{mg} \cdot \mathrm{kg}^{-1}$

\begin{tabular}{|c|c|c|c|c|c|c|c|}
\hline$\overline{\text { Accession }}$ & Injury rating ${ }^{z}$ & Accession & Injury rating & Accession & Injury rating & Accession & Injury rating \\
\hline$\overline{\text { PI } 381840}$ & 1.3 & PI 491344 & 5.0 & PI 491291 & 5.8 & PI 491282 & 6.3 \\
\hline PI 642045 & 2.5 & PI 534552 & 5.0 & PI 491326 & 5.8 & PI 491311 & 6.3 \\
\hline PI 271351 & 2.7 & PI 491266 & 5.2 & PI 491338 & 5.8 & PI 491324 & 6.3 \\
\hline PI 381825 & 2.7 & PI 491273 & 5.2 & PI 491343 & 5.8 & PI 491328 & 6.3 \\
\hline Grif 11940 & 2.8 & PI 491342 & 5.2 & PI 491346 & 5.8 & PI 491339 & 6.3 \\
\hline Gif 11942 & 3.3 & PI 491345 & 5.2 & PI 491349 & 5.8 & PI 534554 & 6.3 \\
\hline PI 641946 & 3.3 & PI 491351 & 5.2 & PI 491357 & 5.8 & PI 491333 & 6.4 \\
\hline PI 381848 & 3.7 & PI 491353 & 5.2 & PI 491361 & 5.8 & PI 642044 & 6.4 \\
\hline PI 381849 & 3.7 & PI 491365 & 5.2 & PI 491362 & 5.8 & PI 381832 & 6.5 \\
\hline PI 636137 & 3.7 & PI 358045 & 5.3 & PI 500815 & 5.8 & PI 491312 & 6.5 \\
\hline PI 195321 & 3.8 & PI 381823 & 5.3 & PI 500818 & 5.8 & PI 491314 & 6.5 \\
\hline PI 358049 & 3.8 & PI 381835 & 5.3 & PI 270456 & 6.0 & PI 491321 & 6.5 \\
\hline PI 534555 & 3.8 & PI 381846 & 5.3 & PI 273662 & 6.0 & PI 491322 & 6.5 \\
\hline PI 370477 & 4.0 & PI 491268 & 5.3 & PI 358059 & 6.0 & PI 491331 & 6.5 \\
\hline PI 381845 & 4.0 & PI 491327 & 5.3 & PI 381831 & 6.0 & PI 500828 & 6.5 \\
\hline PI 438844 & 4.0 & PI 491330 & 5.3 & PI 491280 & 6.0 & PI 491289 & 6.6 \\
\hline PI 438847 & 4.0 & PI 491350 & 5.3 & PI 491295 & 6.0 & PI 500814 & 6.6 \\
\hline PI 438844 & 4.0 & PI 491270 & 5.4 & PI 491299 & 6.0 & PI 491276 & 6.7 \\
\hline PI 438847 & 4.0 & PI 491366 & 5.4 & PI 491300 & 6.0 & PI 491287 & 6.7 \\
\hline PI 358051 & 4.2 & PI 194994 & 5.5 & PI 491303 & 6.0 & PI 491290 & 6.7 \\
\hline PI 381842 & 4.2 & PI 280631 & 5.5 & PI 491305 & 6.0 & PI 491297 & 6.7 \\
\hline PI 381847 & 4.2 & PI 381843 & 5.5 & PI 491319 & 6.0 & PI 491307 & 6.7 \\
\hline PI 381851 & 4.2 & PI 438846 & 5.5 & PI 491335 & 6.0 & PI 491332 & 6.7 \\
\hline PI 491355 & 4.3 & PI 487482 & 5.5 & PI 491336 & 6.0 & PI 500823 & 6.7 \\
\hline PI 381850 & 4.4 & PI 491278 & 5.5 & PI 491340 & 6.0 & PI 491304 & 6.8 \\
\hline PI 491318 & 4.5 & PI 491281 & 5.5 & PI 491302 & 6.2 & PI 491309 & 6.8 \\
\hline PI 491341 & 4.6 & PI 491337 & 5.5 & PI 491306 & 6.2 & PI 491320 & 6.8 \\
\hline PI 534553 & 4.6 & PI 491359 & 5.5 & PI 491310 & 6.2 & PI 370478 & 7.0 \\
\hline PI 491286 & 4.7 & PI 491347 & 5.6 & PI 491316 & 6.2 & PI 491272 & 7.0 \\
\hline PI 491356 & 4.7 & PI 491354 & 5.6 & PI 491323 & 6.2 & PI 491308 & 7.0 \\
\hline PI 381836 & 4.8 & PI 451856 & 5.7 & PI 491325 & 6.2 & PI 491313 & 7.0 \\
\hline PI 381844 & 4.8 & PI 470260 & 5.7 & PI 491329 & 6.2 & PI 491352 & 7.0 \\
\hline PI 419215 & 4.8 & PI 491279 & 5.7 & PI 491334 & 6.2 & Grif 970 & 7.2 \\
\hline PI 491363 & 4.8 & PI 491283 & 5.7 & PI 491360 & 6.2 & PI 381837 & 7.2 \\
\hline PI 381828 & 5.0 & PI 491315 & 5.7 & PI 491367 & 6.2 & PI 491288 & 7.2 \\
\hline PI 381830 & 5.0 & PI 491348 & 5.7 & PI 370474 & 6.3 & PI 491294 & 7.2 \\
\hline PI 381834 & 5.0 & PI 491358 & 5.7 & PI 381854 & 6.3 & PI 368639 & 7.3 \\
\hline PI 442368 & 5.0 & PI 381824 & 5.8 & PI 491252 & 6.3 & PI 639723 & 7.3 \\
\hline PI 491269 & 5.0 & PI 381827 & 5.8 & PI 491267 & 6.3 & PI 379365 & 7.5 \\
\hline PI 491317 & 5.0 & PI 491271 & 5.8 & PI 491274 & 6.3 & $\operatorname{LSD}_{0.05}{ }^{\mathrm{z}}$ & 2.3 \\
\hline
\end{tabular}

LSD $=$ least significant difference.

${ }^{\mathrm{z}} \mathrm{LSD}_{0.05}=2.3$ for comparing genotype means. 
Seeds of bottle gourd plants with high clomazone tolerance or susceptibility in the screening experiment were produced from self-pollinated plants for use in concentrationresponse experiments. A greenhouse experiment was conducted to quantify the relative tolerance of six bottle gourd accessions (Grif 11940, Grif 11942, PI 271351, PI 381825, Grif 970, and PI 368639). Also included were tolerant and susceptible watermelon lines, PI 482324 and PI 271773, respectively, and the commercial bottle gourd cultivar Emphasis (Syngenta, Greensboro, NC). Clomazone concentrations were $0,0.75,1.5,3.0,6.0$, and 12.0 $\mathrm{mg} \cdot \mathrm{kg}^{-1}$ potting medium. The experiment was arranged in a randomized complete block design with five replications and was repeated. Planting dates were 10 Feb. and 26 Apr. 2011. At three weeks after planting, the plants were rated for clomazone injury as described earlier. Relative chlorophyll contents were measured for each plant using a LEAF+ chlorophyll meter (FT Green LLC, Wilmington, $\mathrm{DE})$. Measurements were taken adjacent to the petiole of the oldest leaf. Shoots were excised at the soil surface, and shoot weights were determined for the concentrationresponse experiment.

Data from the two replications of the dose-response experiment were combined and subjected to ANOVA. The treatment by experiment interaction was highly significant; therefore, the data from the two experimental runs were analyzed separately. Nonlinear regression analyses (PROC NLIN; SAS System, 2008, Cary, NC) using the nonparallel doseresponse curve procedure described by Seefeldt et al. (1995) were used to estimate the concentration of clomazone required to cause a midscale injury rating of $5\left(I_{5}\right)$ and $50 \%$ chlorophyll reduction $\left(C_{50}\right)$ for each of the genotypes. The shoot weight data did not converge with the nonlinear regression model; thus, control shoot weights were subjected to ANOVA and shoot weights for the $3.0,6.0$, and $12.0 \mathrm{mg} \cdot \mathrm{kg}^{-1}$ concentrations were converted to percentages of control and subjected to ANOVA. Shoot weight means were compared using the Fisher protected LSD test at $P \geq 0.05$. Correlations among dependent variables were conducted using PROC COR in SAS.

\section{Results and Discussion}

Most of the accessions evaluated in this experiment were moderately or severely injured by clomazone at the application rate of $3.0 \mathrm{mg} \cdot \mathrm{kg}^{-1}$ (Table 1). The overall average injury rating was 5.6 and injury ranged from 1.3 to 7.2 . The four tolerant accessions (Grif 11940, Grif 11942, PI 271351, and PI 381825) with average injury ratings less than 3 and two susceptible accessions (Grif 970 and PI 368639) with injury ratings greater than 7 in the germplasm evaluation experiment were selected for a dose-response experiment to quantify the differences in tolerance observed in the screening experiment.

In the concentration-response experiments, there is considerable difference among bottle gourd genotypes in tolerance to clomazone (Table 2). About three to four times higher clomazone concentrations were required to cause injury ratings of 5.0 or $50 \%$ reduction in chlorophyll content with the tolerant bottle gourd accession Grif 11942 to the susceptible accession Grif 970. Clomazone susceptibility in Grif 970 was similar to that observed with the susceptible watermelon line PI 271773. However, the Grif $11942 \mathrm{IC}_{5}$ estimate was 8.42 , which was greater than the 4.8 observed in PI 482324 , which was one of the most tolerant watermelon lines in a previous study (Harrison et al., 2011). The $I_{5}$ and $C_{50}$ estimates were fairly consistent within genotypes, except for PI 381825 whose estimated $I_{50}$ for injury in experiment $2\left(3.3 \mathrm{mg} \cdot \mathrm{kg}^{-1}\right)$ was about half its $I_{50}$ estimates for injury rating in experiment 1 and $C_{50}$ estimates for chlorophyll content in experiments 1 and $2(6.5,7.5$, and 7.1 $\mathrm{mg} \cdot \mathrm{kg}^{-1}$, respectively). Overall injury ratings and chlorophyll content readings were highly correlated $(R=0.94, P \leq 0.0001)$. Although the chlorophyll measurement procedure is rapid and the instrument is relatively inexpensive (about $\$ 100$ U.S.), it does not appear

Table 2. Estimated clomazone concentrations $\mathrm{s}^{\mathrm{z}}$ in the greenhouse potting medium required to cause injury ratings of $5.0\left(I_{5}\right)$ or $50 \%$ reduction in chlorophyll content $\left(C_{50}\right)$ for seven bottle gourd and two watermelon genotypes.

\begin{tabular}{|c|c|c|c|c|}
\hline \multirow[b]{3}{*}{ Genotype } & \multicolumn{2}{|c|}{ Expt. 1} & \multicolumn{2}{|c|}{ Expt. 2} \\
\hline & Injury rating $I_{5}$ estimate & Chlorophyll content $C_{50}$ estimate & Injury rating $I_{5}$ estimate & Chlorophyll content $C_{50}$ estimate \\
\hline & \multicolumn{4}{|c|}{$\left(\mathrm{mg} \cdot \mathrm{kg}^{-1}\right)$} \\
\hline Emphasis & $3.5 \pm 0.3$ & $3.5 \pm 0.30$ & $3.5 \pm 0.10$ & $3.4 \pm 0.24$ \\
\hline Grif 11942 & $8.2 \pm 0.48$ & $7.6 \pm 0.67$ & $7.7 \pm 0.34$ & $7.5 \pm 0.62$ \\
\hline Grif 970 & $2.5 \pm 0.19$ & $1.5 \pm 0.28$ & $1.9 \pm 0.08$ & $1.5 \pm 0.31$ \\
\hline PI 271351 & $4.2 \pm 0.28$ & $2.8 \pm 0.48$ & $3.3 \pm 0.15$ & $3.5 \pm 0.25$ \\
\hline PI 271773 & $1.4 \pm 0.10$ & $1.7 \pm 0.16$ & $1.3 \pm 0.06$ & $1.7 \pm 0.12$ \\
\hline PI 482324 & $4.8 \pm 0.44$ & $3.7 \pm 0.65$ & $4.0 \pm 1.0$ & $3.5 \pm 0.24$ \\
\hline
\end{tabular}

${ }^{\mathrm{z}} I_{5}$ and $C_{50}$ values were estimated using the log-logistic method described by Seefeldt et al. (1995). Estimate \pm the approximate standard error of the estimate are presented.

Table 3. Control shoot weights and shoot weight as percentage of mean control for seven bottle gourd and two watermelon genotypes by clomazone at 3.0, 6.0, and $12.0 \mathrm{mg} \cdot \mathrm{kg}^{-1}$ greenhouse potting medium in greenhouse concentration-response experiments.

\begin{tabular}{|c|c|c|c|c|c|c|c|c|}
\hline \multirow[b]{3}{*}{ Genotype } & \multicolumn{4}{|c|}{ Expt. 1} & \multicolumn{4}{|c|}{ Expt. 2} \\
\hline & \multirow{2}{*}{$\begin{array}{c}\text { Control } \\
\text { shoot wt }(\mathrm{g})\end{array}$} & $\begin{array}{c}\text { Shoot wt } \\
\text { reduction at } \\
3.0 \mathrm{mg} \cdot \mathrm{kg}^{-1} \\
\end{array}$ & $\begin{array}{l}\text { Shoot wt } \\
\text { reduction at } \\
6.0 \mathrm{mg} \cdot \mathrm{kg}^{-1}\end{array}$ & $\begin{array}{c}\text { Shoot wt } \\
\text { reduction at } \\
12.0 \mathrm{mg} \cdot \mathrm{kg}^{-1} \\
\end{array}$ & \multirow{2}{*}{$\begin{array}{c}\text { Control } \\
\text { shoot wt }(\mathrm{g})\end{array}$} & $\begin{array}{c}\text { Shoot wt } \\
\text { reduction at } \\
3.0 \mathrm{mg} \cdot \mathrm{kg}^{-1} \\
\end{array}$ & $\begin{array}{c}\text { Shoot wt } \\
\text { reduction at } \\
6.0 \mathrm{mg} \cdot \mathrm{kg}^{-1} \\
\end{array}$ & $\begin{array}{c}\text { Shoot wt } \\
\text { reduction at } \\
12.0 \mathrm{mg} \cdot \mathrm{kg}^{-1}\end{array}$ \\
\hline & & & (\% of control) & & & \multicolumn{3}{|c|}{ (\% of control) } \\
\hline Emphasis & 4.8 & 17 & 30 & 36 & 17.1 & 41 & 63 & 69 \\
\hline Grif 11940 & 8.8 & 2 & 24 & 29 & 16.7 & 1 & 28 & 45 \\
\hline Grif 11942 & 8.4 & 19 & -2 & 17 & 21.9 & -9 & 13 & 54 \\
\hline Grif 970 & 9.6 & 48 & 53 & 54 & 21.5 & 53 & 71 & 72 \\
\hline PI 271351 & 6.1 & 19 & 13 & 21 & 18.1 & 19 & 52 & 61 \\
\hline PI 271773 & 2.5 & 43 & 49 & 42 & 11.1 & 80 & 82 & 89 \\
\hline PI 368639 & 9.0 & 28 & 16 & 22 & 24.8 & 9 & 59 & 64 \\
\hline PI 381825 & 5.1 & 2 & -5 & 20 & 17.0 & 9 & 46 & 71 \\
\hline PI 482324 & 4.5 & 1 & 34 & 36 & 19.1 & 48 & 79 & 83 \\
\hline$\underline{\operatorname{LSD}}_{0.05^{\mathrm{z}}}$ & 1.8 & 21 & 28 & 18 & 3.9 & 15 & 11 & 7 \\
\hline
\end{tabular}

LSD $=$ least significant difference.

${ }^{\mathrm{z}} \mathrm{LSD}_{0.05}$ for comparing genotype means within columns. 
to be more accurate than the visual rating for evaluating clomazone tolerance. Portable chlorophyll meters are able to detect previsual damage to soybean treated with glyphosate (Huang et al., 2012). Characterizing chlorophyll and fluorescence as influenced by clomazone pre-visual injury in field would be valuable to compliment the greenhouse data set.

The differences in shoot weight reduction among genotypes in response to clomazone corresponded to the differences that were observed with injury ratings and chlorophyll contents. Shoot weight reduction differed among genotypes for all treatments; relative weight reduction for the susceptible genotype Grif 970 was greater than that for the tolerant genotype Grif 11942 for all treatments. Control shoot weights were much greater in experiment 2 than in experiment 1 . This increase was likely due to the greater sunlight intensity and longer daylength in experiment 2 planted on 26 Apr. than in experiment 1 planted on $10 \mathrm{Feb}$. The more rapid growth in experiment 2 resulted in a greater percentage reduction in shoot weight by clomazone as compared with experiment 1 . Because of the slower growth, the differences in shoot weight between control and clomazone injured plants were not as great in experiment 1 as in experiment 2 . Injury ratings and chlorophyll contents did not vary greatly between the experiments (data not presented). Even though growth rates varied greatly between the experiments, the relative difference in clomazone response between genotypes was similar in both environments (Table 3 ). Variability of tolerance as affected by cucurbit variety compliments previous studies (Boyhan et al., 1995; Cohen et al., 2008; Grey et al., 2000).

\section{Conclusion}

The relatively high level of clomazone tolerance of bottle gourd genotypes such as Grif 11942 indicates that the herbicide could be used for weed management with tolerant cultivars. Further research is required to demonstrate that tolerance holds up under field conditions; however, in previous research, watermelon genotypes showed similar difference in tolerance using this greenhouse procedure and in field evaluations (Harrison et al., 2011). Clomazone may not be safe for use on the most susceptible genotypes such as Grif 970. Research at the U.S. Vegetable Laboratory is focused on developing bottle gourd genotypes useful for rootstocks for grafted watermelons. As watermelon tolerance to clomazone is marginal, we intend to determine whether the tolerance of the rootstock genotype affects the response of the scion watermelon plant. It is feasible that rootstocks with high tolerance such as Grif 11942 may reduce the injury to the scion with grafted watermelon. This result may allow the use of higher clomazone rates which control weeds more effectively than the relatively low rates that are currently recommended for watermelon (Anonymous,
2005). On the other hand, susceptible bottle gourd genotypes are undesirable for rootstocks if clomazone is used for weed management. Future experiments could compare tolerant bottle gourd rootstocks grafted to either sensitive watermelon or sensitive bottle gourd scions to determine if the relative reduction in injury is the same. PI 381825 was collected in India and is genetically different from many other genotypes (Levi et al., 2009). In addition to relatively high tolerance to clomazone, it is resistant to zucchini yellow mosaic virus (Ling and Levi, 2007) and moderately resistant to powdery mildew (Kousik et al., 2008). Because of these attributes, further evaluation of this genotype as a rootstock for grafting cucurbits is warranted.

\section{Literature Cited}

Adkins, J.I. 2011. Herbicide use in grafted triploid watermelon [Citrullus lanatus (thunb.) Matsumura and Nakai] (Order No. 3514926). Available from ProQuest Dissertations \& Theses Global; SciTech Premium Collection (1018715311), Clemson Library loan. Jan. 2012. <http://libproxy. clemson.edu/login?url=http://search.proquest. com/docview $/ 101871531$ ? accountid=6167 $>$.

Al-Khatib, K., S. Kadir, and C. Libbey. 1995. Broadleaf weed control with clomazone in pickling cucumber (Cucumis sativus). Weed Technol. 9:166-172.

Anonymous. 2005. Command 3ME herbicide label, EPA Reg. No. 279-3158. FMC Corp, Philadelphia, PA.

Boyhan, S.P., G.E. Kovach, B.J. Norton, D.R. Abrahams, H.M. Hollingsworth, and J.M. Dangler. 1995. Preemergence herbicides for cantaloupe and watermelon. J. Veg. Crop Prod. 1:79-92.

Cohen, R., H.M. Eizenberg, M. Edelstien, C. Horev, T. Lande, A. Porat, G. Achdari, and J. Herschenhorn. 2008. Evaluation of herbicides for selective weed control in grafted watermelon. Phytoparasitica 36:66-73.

Colla, G., A. Fanasca, M. Cardarelli, Y. Rouphael, F. Saccardo, A. Graifenberg, and M. Curadi. 2005. Evaluation of salt tolerance in rootstocks of Cucurbitaceae. Acta Hort. 697:469-474.

Colla, G., Y. Rouphael, C. Leonardi, and Z. Bie. 2010. Role of grafting in vegetable crops grown under saline conditions. Scientia Hort. 127:147-155.

Cutler, H.C. and T.W. Whitaker. 1967. Cucurbits from the Techuacan Caves, p. 212-219. In: D.S. Byers (ed.). The prehistory of the Tehuacan valley: Environment and subsistence. University of Texas Press, Austin, TX.

Decker-Walters, D., J.E. Staub, and S.M. Chung. 2001. Diversity in landraces and cultivars of bottle gourd (Lagenaria siceraria: Cucurbitaceae) as assessed by random amplified polymorphic DNA. Genet. Resources Crop Evol. 48:369-380

Decker-Walters, D.S., M. Wilkins-Ellert, S.M. Chung, and J.E. Staub. 2004. Discovery and genetic assessment of wild bottle gourd (Lagenaria siceraria (Mol.) Standley; Cucurbitaceae) from Zimbabwe. Econ. Bot. 58:501-508.

Erickson, D.L., B.D. Smith, A.C. Clarke, D.H. Sandweiss, and N. Tuross. 2005. An Asian origin for a 10,000-year-old domesticated plant in the Americas. Proc. Natl. Acad. Sci. USA 102:18315-18320.
Figueroa, R. and M. Kogan. 2005. Clomazone selectivity among six cucurbit crops. Agrociencia 39:611-618.

Grey, T.L., D.C. Bridges, and D.S. NeSmith. 2000. Tolerance of cucurbits to the herbicides clomazone, ethanlfluralin, and pendimethalin. II. Watermelon. HortScience 35:639-641.

Harrison, Jr., H.F., and D.M. Jackson. 2011 Greenhouse assessment of differences in clomazone tolerance among sweetpotato cultivars. Weed Technol. 25:501-505.

Harrison, Jr., H.F., and A.P. Keinath. 2003. Glasshouse assessment of clomazone response in U.S. pumpkin cultivars. Crop Prot. 22:795798.

Harrison, Jr., H.F., K.S. Kousik, and A. Levi. 2011. Identification of Citrullus lanatus germplasm lines tolerant to clomazone herbicide. HortScience 46:684-687.

Hines, T.E. and H.P. Wilson. 1992. Varietal tolerance to clomazone. Proc. Northeastern Weed Sci. Soc. 46:27 (abstr.).

Hopen, H.J., R.L. Hughes, and B.A. Michaelis. 1992. Selectivity among cabbage cultivars to clomazone. Weed Technol. 7:471-477.

Huang, Y., S.J. Thomson, W.T. Molin, and K.N. Reddy. 2012. Early detection of soybean plant injury from glyphosate by measuring chlorophyll reflectance and fluorescence. J. Agr. Sci. 4:117-124.

Jeffrey, C. 1967. Cucubitaceae, p. 47-53. In: E. Milne-Redlead and R.M. Polhill (eds.). Flora of tropical east Africa. Crown Agents, London, UK

Keifer, D.W. 1989. Tolerance of corn (Zea mays) lines to clomazone. Weed Sci. 37:622-628.

Kousik, C.S., R.S. Donahoo, and R. Hassell. 2012. Resistance in watermelon rootstocks to crown rot caused by Phytophthora capsici. Crop Prot. $39: 18-25$.

Kousik, C.S., A. Levi, K-S. Ling, and W.P. Wechter. 2008. Potential sources of resistance to cucurbit powdery mildew (Podosphaera xanthii) in US plant introductions (PI) of Lagenaria siceraria (bottle gourd). HortScience 43:1359-1364.

Levi, A., J.A. Thies, K. Ling, A.M. Simmons, C.S. Kousik, and R. Hassell. 2009. Genetic diversity of Lagenaria siceraria and identification of accessions useful for the development of disease and pest resistant rootstocks. Plant Genet. Resources 7:216-226.

Ling, K. and A. Levi. 2007. Sources of resistance to zucchini yellow mosaic virus in Lagenaria siceraria germplasm. HortScience 42:11241126.

Ling, K., A. Levi, S. Adkins, C.S. Kousik, G. Miller, R. Hassell, and A.P. Keinath. 2013. Development and field evaluation of multiple virus-resistant bottle gourd (Lagenaria siceraria). Plant Dis. 97:1057-1062.

Morimoto, Y., P. Maundu, M. Kawase, H. Fujimaki, and H. Morishima. 2006. RAPD polymorphism of the white-flowered gourd Lagenaria siceraria (Molina) Standl. landraces and its wild relatives in Kenya. Genet. Resources Crop Evol. 53:963-974.

Mudge, C.R., E.P. Webster, C.T. Leon, and W. Zhang. 2005. Rice (Oryza sativa) cultivar tolerance to clomazone in water seeded production. Weed Technol. 19:907-911.

Richardson, III. J.B., 1972. The pre-Columbian distribution of the bottle gourd (Lagenaria siceraria): A re-evaluation. Econ. Bot. 26:265-273.

Scherder, E.F., R.E. Talbert, and S.D. Clark. 2004. Rice (Oryza sativa) cultivar tolerance to clomazone. Weed Technol. 18:140-144. 
Seefeldt, S.S., J.E. Jensen, and E.P. Fuerst. 1995. Log-logistic analysis of dose response relationships. Weed Technol. 9:218-227.

Sikkema, P.H., C. Shropshire, and N. Soltani. 2006. Effect of clomazone on various market classes of dry beans. Crop Prot. 26:943947.
Staub, J., L. Crubaugh, H. Baumgartner, and H. Hopen. 1991. Screening of the cucumber germplasm collection for tolerance to clomazone herbicide. Cucurbit Crop Genet. Rep. 14:22-24.

Yetisir, H., M.E. Çaliskan, S. Soylu, and M. Sakar. 2006. Some physiological and growth responses of watermelon (Citrullus lanatus
(Thunb.) Matsum. and Nakai) grafted onto Lagenaria siceraria to flooding. Environ. Expt. Bot. $58: 1-8$.

Zhang, W., E.P. Webster, D.C. Blouin, and S.D. Linscombe. 2004. Differential tolerance of rice (Oryza sativa) varieties to clomazone. Weed Technol. 18:73-76. 